\title{
California Island Rediscovery: building an archive to improve conservation today and equip the historical ecologist of tomorrow
}

\author{
SCOtT A. Morrison ${ }^{1, *}$, T. SCOTt Sillett ${ }^{2}$, W. Chris FunK ${ }^{3}$, \\ Cameron K. Ghalambor ${ }^{3}$, and Torben C. Rick ${ }^{4}$ \\ ${ }^{1}$ The Nature Conservancy, 201 Mission St., 4th Floor, San Francisco, CA 94105 \\ ${ }_{2}^{2}$ Migratory Bird Center, Smithsonian Conservation Biology Institute, \\ National Zoological Park, MRC 5503, Washington, DC 20013 \\ ${ }^{3}$ Department of Biology and Graduate Degree Program in Ecology, Colorado State University, Fort Collins, CO 80523 \\ ${ }^{4}$ Department of Anthropology, National Museum of Natural History, Smithsonian Institution, Washington, DC 20013
}

\begin{abstract}
An understanding of how past conditions have shaped present-day ecological patterns and trends is critical to science-based conservation management. Unfortunately, the records, specimens, and objects historical ecologists need to help generate that understanding are often lacking. And because of a general underinvestment by society in systematic collection and museum curation, future historical ecologists may be similarly limited in their ability to investigate conditions regarding our present day. Given the importance of historical data and materials in contemporary conservation decision-making, we suggest it is incumbent upon resource managers and scientists to ask whether additional research efforts are needed to document past and present conditions of the places and resources of their interest. Here, we discuss how such an inquiry was applied to the terrestrial and nearshore environments of Santa Cruz Island, California, USA. The island harbors numerous endemic taxa, important archaeological and fossil sites, and rich cultural significance. It also has undergone dramatic and ongoing alteration due to past and present human activities. We describe an interdisciplinary effort to identify information gaps regarding past and present conditions of the island. In many cases, filling those gaps will require a research focus on a broader geography and suite of resources, including the archipelago in which the island sits and mainland "sister sites." An initiative to improve collection and retention of priority information could be a basis of interdisciplinary and multi-institutional collaboration and could be designed to foster environmental education and citizen science programs that engage the next generation of conservationists. An outcome of this initiative would be an archive of materials and data to inform the historical ecologists and conservationists of the future, and to help conservationists today ensure that the resources they deem most important will be stewarded successfully into that future.
\end{abstract}

RESUMEN.-La comprensión de cómo las condiciones del pasado moldearon los patrones y las tendencias ecológicas actuales es fundamental para la conservación basada en la ciencia. Desafortunadamente, con frecuencia se carece de los registros, especímenes y objetos que los ecólogos históricos necesitan para ayudar a generar tal comprensión. Debido a una insuficiente inversión general por parte de la sociedad, para la colecta sistemática y la preservación de los museos, los futuros ecólogos históricos podrían estar igualmente limitados en su capacidad para investigar las condiciones actuales. Dada la importancia de los datos y de los materiales históricos para tomar decisiones en la conservación actual, sugerimos que los responsables del manejo de recursos y los científicos deberían analizar si se requieren iniciativas de investigación adicionales para documentar las condiciones pasadas y presentes de los lugares y los recursos de interés. Aquí discutimos cómo se aplicó tal investigación a los ambientes terrestres y costeros de la Isla Santa Cruz, CA (EE.UU.). La isla alberga numerosos taxa endémicos, importantes sitios arqueológicos y fósiles, y un gran valor cultural. También experimentó una alteración dramática y continua debido a las actividades humanas pasadas y presentes. Describimos una labor interdisciplinaria para identificar lagunas de información de las condiciones pasadas y presentes de la isla. En muchos casos, el llenar esas lagunas requerirá que la investigación se enfoque en una geografía más amplia y en un conjunto de recursos, incluyendo el archipiélago en el que se ubica la isla y los "sitios asociados" del continente. Una iniciativa para mejorar la colección y la retención de información prioritaria podría consistir en un marco de colaboración interdisciplinaria y multiinstitucional y estar diseñado para promover programas de educación ambiental y de ciencia ciudadana que involucren a las próximas generaciones de conservacionistas. El resultado de esta iniciativa consistiría en un archivo de datos y de materiales que sirvan para informar al ecólogo histórico y al conservacionista del futuro, y para ayudar a los ecólogos contemporáneos a asegurar que los recursos que se consideren más importantes sean administrados exitosamente en el futuro.

*Corresponding author: smorrison@tnc.org

TSS (D) orcid.org/0000-0002-7486-0076

TCR (D) orcid.org/0000-0002-7486-0076 
When 16th-century European explorers "discovered" the Pacific Coast of North America, some described a large, elongate island named "California" (Polk 1991). The cartographic depiction of California as an island (Fig. 1) persisted for generations, appearing on scores of maps originating from Europe and Asia into the 19th century. Eventually, an increase in exploration, access to information, and scientific and technological sophistication led to the "rediscovery" of a continental California that had long been hidden in plain sight.

That history is instructive when examining the state of knowledge regarding the natural and cultural history of the actual islands offshore of present-day California, USA, and Baja California, Mexico (Fig. 2). These island ecosystems have experienced significant modification resulting from human activity. Native Americans occupied most of the islands from at least 13,000 years ago to the early 1800 s, and the end of that era coincided with the introduction of many nonnative herbivores and predators associated with livestock ranching (Rick et al. 2014). Sheep (Ovis aries), cattle (Bos taurus), pigs (Sus scrofra), and other introduced species caused widespread destruction of vegetation communities and erosion of soils, with cascading ecological effects (Roemer et al. 2002, Perroy et al. 2012). Similarly in the marine realm, the fur and whale oil trade caused dramatic declines in marine mammal populations, with lasting repercussions for coastal ecosystems (Ogden 1975). Much of the degradation of the islands and their coastal ecosystems occurred before they were systematically surveyed by scientists. Consequently, much uncertainty exists about the ecology of the islands prior to the ranching era and fur trade. An understanding of these historic conditions is highly relevant to management of the islands' natural and cultural resources today (e.g., Figs. 3-6). In other words, we have much on the islands to "rediscover" and would accrue many benefits from doing so.

Historical ecology aims to elucidate past conditions and their relationship to current conditions and trends. It can also support conservation decision-making by helping managers understand the relationship between natural and cultural histories and the baseline conditions of species and ecosystems prior to the modern era (Swetnam et al. 1999, Winker 2004, Erlandson and Rick 2010, Braje and
Rick 2013, Rick and Lockwood 2013, Szabó 2015, Barnosky et al. 2017). Such information can be invaluable when setting goals for ecological restoration and biodiversity management (Higgs et al. 2014). Museum archives, including specimen collections and historical records, photos, and documents, often provide essential resources for such investigation (e.g., McClenachan 2009, Vellend et al. 2013, Sholts et al. 2016). Analytical and technological advances, such as in the molecular sciences, have unlocked information from historical records unimagined at the time of the original collection (Willis et al. 2008, Holmes et al. 2016, Nualart et al. 2017). Future scientists will be able to glean even more information-if they have appropriate source materials.

Societal investment in systematic collection and curation of museum archives has been notably insufficient over recent decades (Suarez and Tsutsui 2004, Bradley et al. 2014, Sholts et al. 2016). That this underinvestment coincides with an era of such marked global dynamism is especially unfortunate (Pecl et al. 2017). Historical ecology research today can be hindered by the patchiness of the source materials needed on which to base analyses (Szabó 2015). If present-day conditions are poorly represented in collections and archives, historical ecologists of the future may be similarly limited in their ability to investigate today's environmental change. Conservation managers working in the decades and centuries ahead may be disadvantaged in turn (Krishtalka and Humphrey 2000).

To reduce this risk, Morrison et al. (2017) encouraged scientists and managers to assess the sufficiency of present-day documentation regarding their resources of interest. To focus that inquiry, they recommended that scientists and managers envision themselves working in their current role a century from now and ask what their future self would most wish their present-day self had done to better position them for success. Here, we present a case study in which we apply this inquiry to the resources of one of the California islands, Santa Cruz. We posit that undertaking an environmental "horizon scanning" exercise (sensu Sutherland and Woodroof 2009) with the aim of identifying and addressing key gaps in knowledge and records would benefit both the current and future management of the island and its resources. 


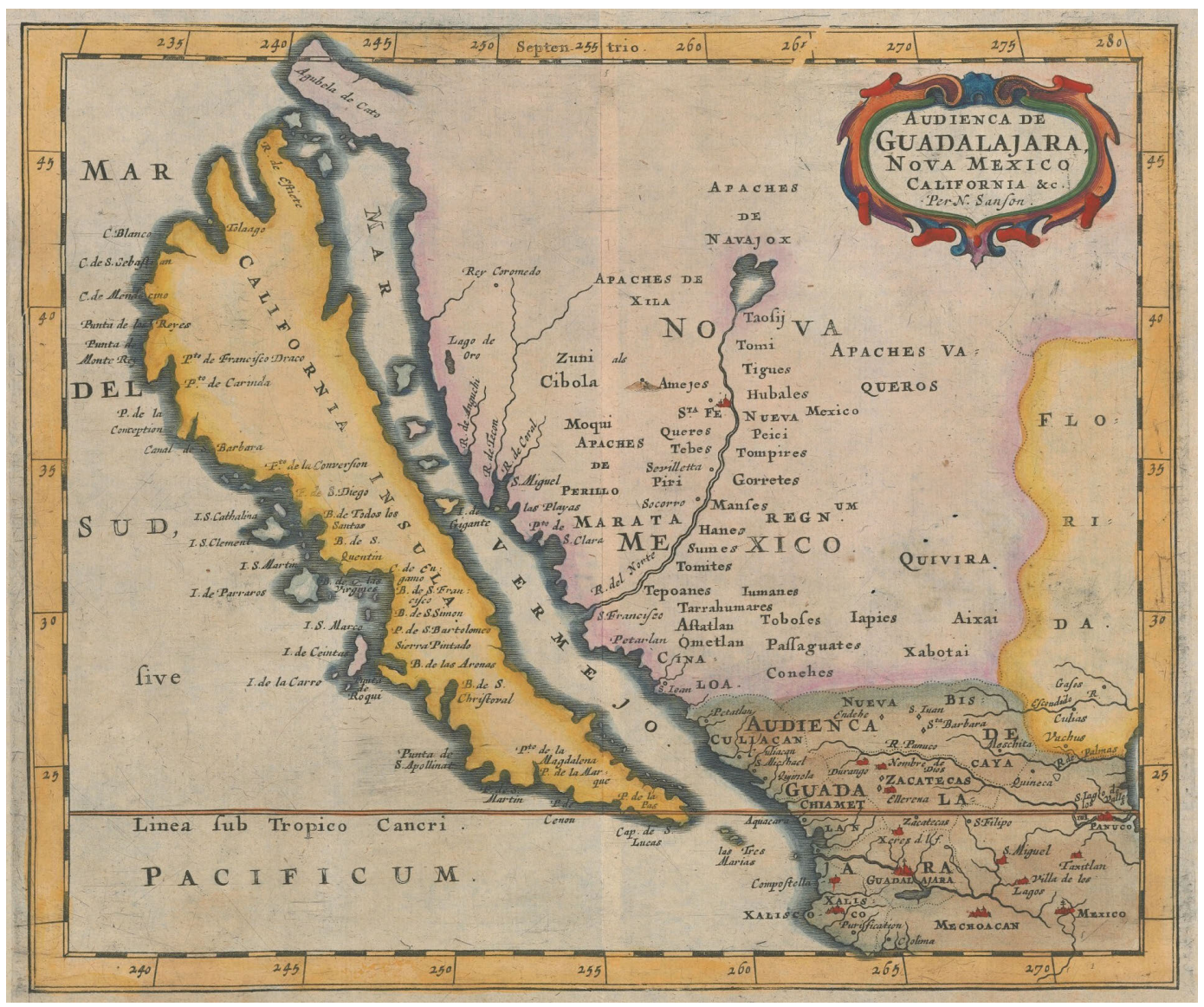

Fig. 1. California mapped as an island, ca. 1657. Image: Glen McLaughlin Map Collection of California as an Island, Stanford University Libraries.

\section{Focal Place and Resources}

To undertake this type of inquiry, managers and scientists must first define a geographic scope and resources of interest (Morrison et al. 2017). Despite a broader research and conservation interest in the whole of the California archipelago, we focused the inquiry herein on a single island, in order to reduce complexity by focusing, at least initially, on a discrete ecological and administrative unit. We recognize that any inquiry focused on the resources of one place would likely need to expand in scope to include other places and resources. For example, managing a bird species on one island may require understanding its metapopulation dynamics across an archipelago, or protecting a rare plant as climates change may require its translocation to another island. Management questions pertaining to one place can help elucidate the priorities for information gathering from other places. Our approach is analogous to using a protected area in a continental setting to base an initial inquiry; the scope of the inquiry may subsequently expand to include areas outside of the original focal area and encompass a broader constellation of sites, akin to the archipelago context we discuss here.

Santa Cruz Island, $250 \mathrm{~km}^{2}$ in area and approximately $30 \mathrm{~km}$ from the mainland coast, is the largest and most biodiverse of the California Channel Islands (Schoenherr et al. 1999; Fig. 2). It is characterized by 2 parallel mountain ranges flanking a fault-line central valley and experiences a mediterranean climate of cool, wet winters and warm, dry summers. The island is home to many taxa endemic to the island or to the broader archipelago that extends into Baja California. 


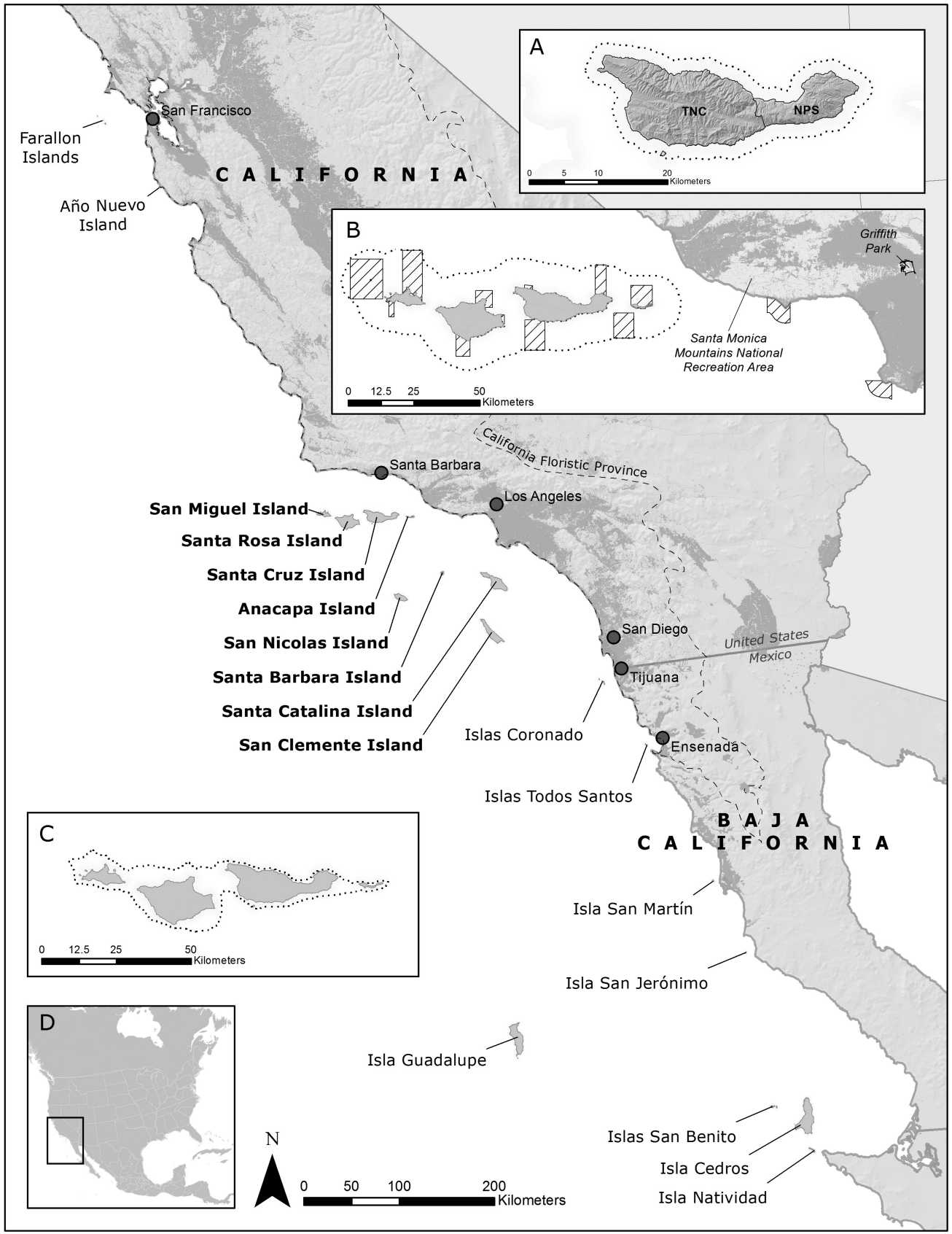

Fig. 2. The Pacific islands of Alta and Baja California. Islands named in bold font comprise the California Channel Islands. Darker gray areas on the mainland represent urban or agricultural development. Inset A shows detail of Santa Cruz Island, including the boundary between The Nature Conservancy and the National Park Service properties, and the dotted line depicts the nearshore boundary of Channel Islands National Park. The park also includes San Miguel, Santa Rosa, Anacapa, and Santa Barbara islands. Inset B shows the northern Channel Islands and nearby mainland protected areas. Such places may present opportunities to establish "mainland island" sister sites for long-term comparison and as a base for "Island Rediscovery" citizen science and outreach programs that are generally more accessible to urban centers than the actual islands. The dotted line depicts the boundary of the Channel Islands National Marine Sanctuary; hatched areas represent state or federal marine reserves. Inset C depicts the shoreline (dotted line) of the Santarosae landmass, approximately 12,000 years before present. Inset D shows the location of the California islands in North America. Cartography: Corrine Grainger. 
Santa Cruz Island's value as a case study for this inquiry is enhanced by its discrete bounds as a protected area and as an island, and by its nestedness within a broader archipelago and various jurisdictional boundaries. The Nature Conservancy, an international nongovernmental organization, owns $76 \%$ of the island and the U.S. National Park Service owns the remainder, including a marine buffer extending one nautical mile $(1.8 \mathrm{~km})$ from the coast (Fig. 2A). Santa Cruz is one of 5 islands in Channel Islands National Park. The Channel Islands National Marine Sanctuary, administered by the U.S. National Oceanographic and Atmospheric Administration, encompasses 6 nautical miles $(11.1 \mathrm{~km})$ from the park islands, with a network of state and federally decreed marine protected areas within those bounds (Fig. 2B).

Santa Cruz Island is biogeographically and culturally linked to other California islands. The Pacific islands of California and Baja California occur within the California Floristic Province (Stebbins and Major 1965). When sea levels were lower in the last glacial period, Santa Cruz Island was connected to the 3 other northern Channel Islands as a single land mass, Santarosae, that broke apart approximately 9000 years ago (Reeder-Myers et al. 2015; Fig. 2C). Like most California islands, Santa Cruz Island shares a history of land use that includes Native American uses, fur hunting, ranching, and now conservation and public visitation (Rick et al. 2014). The island's natural communities also share many attributes with the mainland coast, albeit without many of the effects of today's large human population. Thus, the ecology of the California islands relative to that of the mainland will continue to provide an interesting comparison.

Santa Cruz Island is undergoing dramatic ecological transition. All ungulates have been removed, which has released the vegetation from large vertebrate herbivory (Morrison 2011). Succession is largely unmanaged, save for efforts to eradicate and control some invasive plant species (Cory and Knapp 2014). While the recovery of native vegetation will benefit many species, the current trajectory of the ecosystem may be in many ways quite novel. Prior to the "ranching era," Native Americans lived on the island for millennia, harvesting a wide variety of marine resources and terrestrial plants and animals, as well as burning the landscape and creating large shell middens and other sites that physically altered the landscape (Rick et al. 2014). In contrast, the terrestrial environment in the "conservation era" is largely free of the resource extraction and landscape alteration (e.g., vegetation burning) associated with sizable human occupation. This could have important implications for species that require more open or early successional habitats (e.g., Loggerhead Shrike Lanius ludovicianus; Cabellero and Ashley 2011) or that were historically harvested (e.g., Braje et al. 2015). Compounding the ecological flux spurred by the introductions and removals of invasive species are the myriad effects of global change. Climate change is generally expected to lead to drier conditions in coastal southern California (Cayan et al. 2008). However, the strong influence of local marine conditions on the climate of the islands, such as fog patterns (Carbone et al. 2013), makes projection difficult. The physical isolation of the island may limit the ability of some species to disperse and thereby track the conditions they need as climates change, potentially exacerbating extinction risk (Morrison 2014).

The conservation values that are priorities in management decisions are in part defined by the mandates of the landowners. Channel Islands National Park was established in 1980 to protect "nationally significant natural, scenic, wildlife, marine, ecological, archaeological, cultural, and scientific values of the Channel Islands" (emphasis added to highlight an uncommon explicit purpose of a U.S. National Park, one that incidentally also aligns well with the aims of the inquiry we discuss here). The park also is required to protect the "wilderness character" of some areas of Santa Cruz Island (NPS 2015). The Nature Conservancy's mission is to preserve biodiversity. We therefore assume that the managers of Santa Cruz Island in the future will seek to maintain habitat for and protect populations of rare and endemic taxa. To achieve that goal as climates change may require translocation of some species to other places (Morrison 2014). We also assume that managers might prioritize protection of species that also occur on the mainland but that may be imperiled there because of direct and indirect impacts of human land uses, as well as species that occur on other California islands that may not remain viable within their current range. 


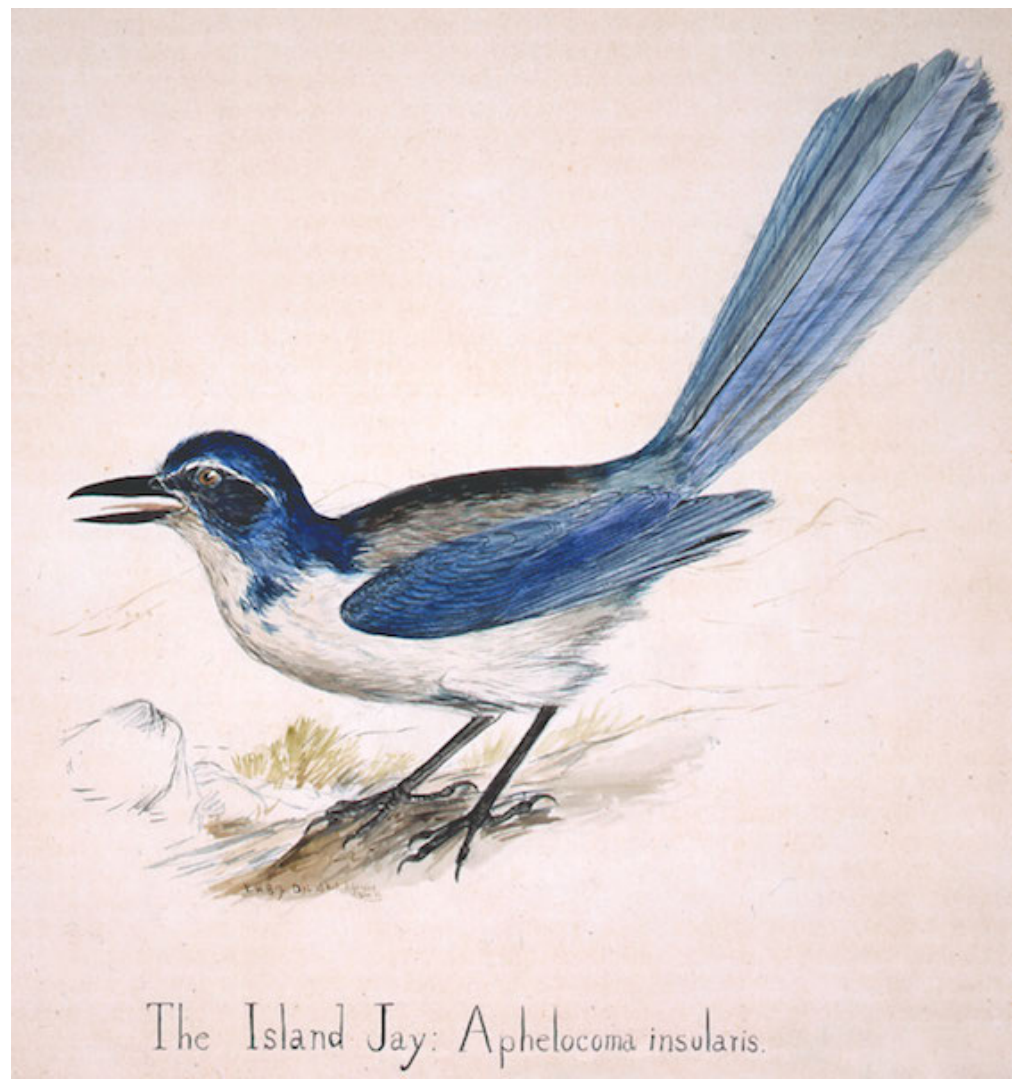

Fig. 3. Painting of an Island Scrub-Jay (Aphelocoma insularis) from the year the species was first described by Henshaw (1886). Although the species once occurred across the northern Channel Islands (Fig. 2C), it currently occurs only on Santa Cruz Island. Concerns about species viability have led managers to ask whether a second population should be reestablished on neighboring Santa Rosa Island, where fossil evidence suggests it occurred until at least roughly 1000 years ago. A key input into a decision about translocating jays is understanding when and why the Santa Rosa population went extinct (Morrison 2014). Collins (2009) asked if there was any reference to jays on Santa Rosa Island in the historical record; he also chronicled the extent to which trained observers even visited the island during the latter 1800s, prior to the extreme vegetation loss caused by introduced sheep. Through this focused inquiry, Collins discovered field notes from an ornithologist in 1892 who noted that the ranch manager told him "there are (Aphelocoma) jays on the island." This finding suggests jays may have persisted on Santa Rosa Island into historic time, which has important implications not just for jay management but also for restoration of the island, where recovery of native vegetation may be limited by the absence of an animal seed disperser of oaks (Quercus spp.) and pines (Pinus spp.) (Pesendorfer et al. 2016). Painting: Eli W. Blake, Jr. Image: Channel Islands Archives of the Santa Barbara Museum of Natural History.

\section{A LoOK BACK From the Future}

Santa Cruz Island has been the focus of much paleontological, archaeological, ethnohistorical, biological, and historical research, much of which can help address broader historical ecological questions (see Rick et al. 2018). Future conservationists will have the benefit of the products of that scientific enterprise, including a variety of remotely sensed and other environmental data streams. The question is whether that collective effort provides a record sufficiently complete for the conservation needs of today and tomorrow. In 2016, we convened a multidisciplinary workshop to ask whether additional effort is needed to ensure that critical materials or observations of past decades and centuries, and present-day conditions, are not lost (see Morrison et al. 2017). The aim of the workshop was to answer 3 questions regarding Santa Cruz Island: (1) How should we better document past conditions? (2) How should we better document present 


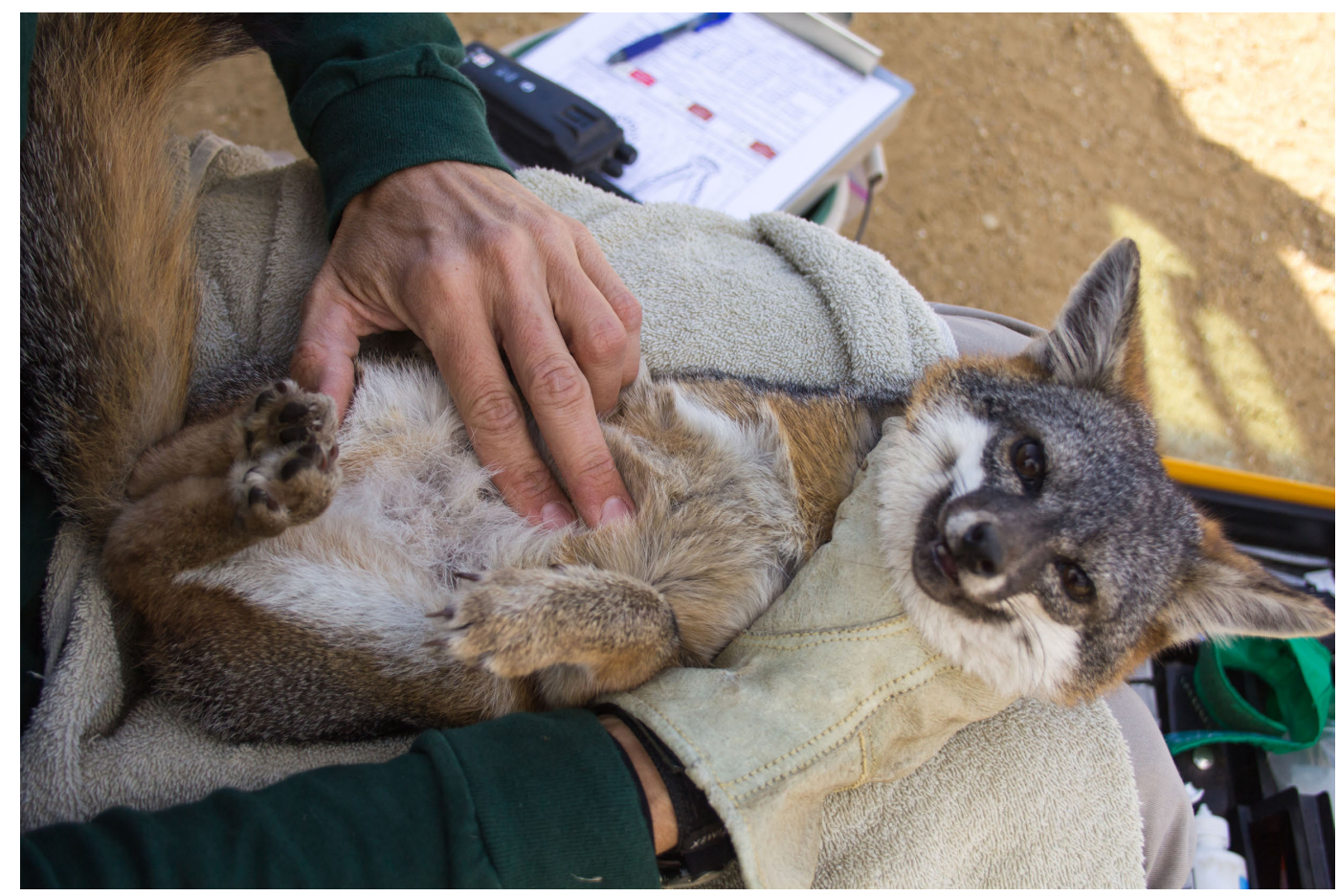

Fig. 4. A field researcher examines an island fox (Urocyon littoralis) on Santa Catalina Island, California. Managers monitor the demography and health of fox populations on each of 6 islands where they occur, including Santa Cruz. Biological samples collected as part of these efforts have enabled multiple lines of investigation, which have improved not only fox conservation management but also understanding of the ecological and human history of the islands. Advances in genomics have uncovered the fox colonization history of the islands, current and historic population sizes, adaptive differences among islands, and recent movement among islands potentially mediated by humans (Hofman et al. 2015, Funk et al. 2016, Robinson et al. 2016). Carbon isotope analysis of bones of ancient and modern island foxes has also allowed characterization of diet among islands and over time, revealing a generalist diet that has varied as resource availability has changed due to climatic and human influences, which suggests a general resilience of the species to changing conditions (Hofman et al. 2016). Photo: Jason G. Goldman.

conditions? And (3) how should we better capitalize on materials collected historically or in the present to make the most informed conservation decisions?

To focus such an inquiry, the resources and issues pertaining to a place can be categorized in multiple ways. For Santa Cruz Island, we divided our multidisciplinary workshop into 4 discussion groups focused on terrestrial and freshwater fauna, terrestrial and freshwater flora, coastal and marine systems, and a category dubbed "cultural" that encompassed paleoecology, archaeology, anthropology, and historical ecology. More detail on the recommendations from those discussions are provided in Boser et al. (2018), Gleason et al. (2018), Randall et al. (2018), and Rick et al. (2018). As expected, these groups found their discussions overlap- ping. For example, isolating a discussion on fauna from one on vegetation was difficult. Indeed, we encouraged participants to seek cross-disciplinary connections, especially as they synthesized their recommendations and considered opportunities for collaboration in implementation. Also as expected, recommendations often included collecting comparative data from or near other islands of the archipelago and the mainland.

\section{Documenting the Past}

The highest priority for "better documenting the past" may be to accelerate the study of resources vulnerable to near-term loss from environmental exposure (Rick et al. 2018). For example, much of the perimeter of Santa Cruz Island is lined with archeological sites 


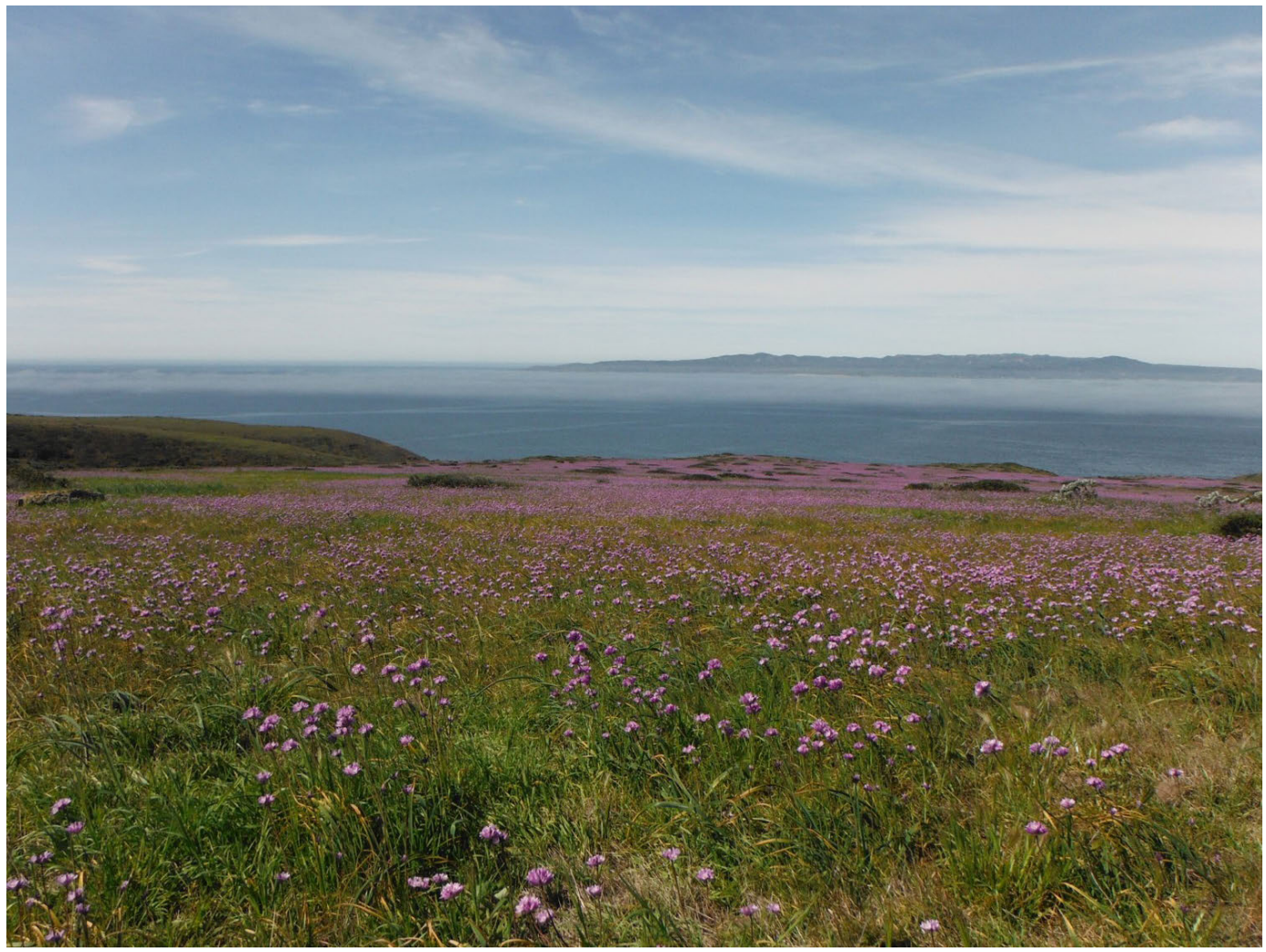

Fig. 5. Flowering blue dicks (Dichelostemma capitatum) on Santa Cruz Island, California; Santa Rosa Island can be seen in the distance. Following the eradication of introduced ungulates from Santa Cruz Island and the corresponding release from herbivory, conservation managers have been monitoring changes in vegetation. One area expected to experience recovery to native shrubland was the extensive grasslands/flowerfields on the northwestern portion of the island. Instead, the area has maintained largely herbaceous cover with a conspicuous abundance of blue dicks. Current archaeobotanical research is investigating whether these areas may have been actively managed by the island Chumash, who harvested the corm-producing species as a dietary staple for thousands of years (Kristina M. Gill personal communication). Understanding such historical ecological context is important for setting science-based restoration goals (Randall et al. 2018). Photo: Eamon O’Byrne.

experiencing erosion and destruction due to sea level rise and storm surge (Reeder et al. 2012). These erosional forces follow roughly a century and a half of soil loss and slope destabilization due to overgrazing by livestock (Pinter and Vestal 2005). While vegetation recovery will help stabilize slopes, it will also obscure some archeological and cultural resources, such as topographic features that may indicate prehistoric or historic structures. Cultural materials from these sites provide a window into the past that can help managers understand how human interactions affected historic baseline conditions. Rapid inventory and excavation of priority sites is critical, as those opportunities will simply not exist in the future.
Similarly time-sensitive is the capture of records, institutional knowledge, and ephemera vulnerable to loss with generational transitions, such as when island researchers and staff retire. Synthetic historical accounts (e.g., Livingston 2006, Daily 2012), unpublished data, field notes, and material collections of researchers may be especially valuable. Supporting interns to assist late-career researchers in archiving materials may be helpful. Documenting experiences and perspectives of island researchers, managers, eradication teams, boat captains, rangers, and frequent visitors could provide data concerning past socioecological conditions. Such documentation could be facilitated by developing programs for recording oral histories, digitizing 


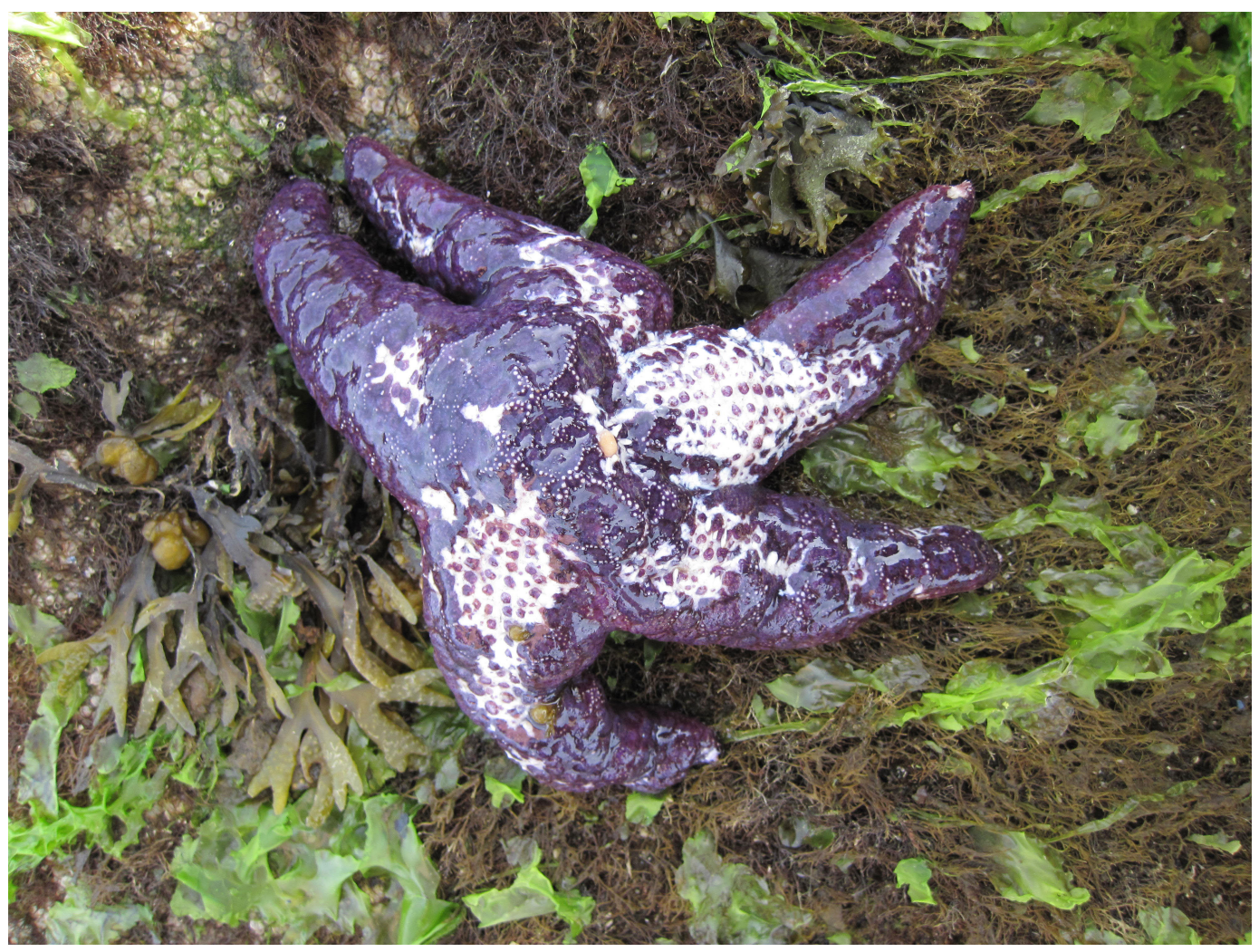

Fig. 6. An ochre sea star (Pisaster ochraceus) displaying symptoms of sea star wasting disease during a recent massmortality event across the west coast of North America. Elucidating the cause of the sudden die-off has been aided by genetic analyses of archived museum specimens, including samples from the California Channel Islands and including samples collected as many as 90 years prior to the event (Hewson et al. 2014). Long-term community and environmental monitoring at various locations along the coast-including monitoring by citizen scientists-has been instrumental in understanding drivers of the epizootic as well as its ecological impact (Menge et al. 2016, Pfister et al. 2016). Photo: C. Melissa Miner.

and cataloging gray literature, creating digital map services that allow crowdsourced annotation to capture "island lore" associated with landmarks (e.g., the story behind a road name or historic structure), and establishing and promoting repositories for photographs or other memorabilia of the island so they are not discarded by disinterested heirs.

In many ways, we are just beginning to tap the potential of deep historical data to inform conservation of marine and terrestrial ecosystems. Braje et al. (2015), for example, used 10,000 years of archaeological harvest and abundance data, in tandem with historical catch records, to help determine the best places for outplanting black abalone (Haliotis cracherodii) populations on the California islands. On shore, archaeobotanical research is revealing the role of ancient Native American resource use in shaping present-day vegetation community distributions, recasting assumed natural landscapes as perhaps cultural landscapes, with important implications for setting restoration goals (Gill 2016; Fig. 5). These and other projects are helping us understand how past human activities shape the patterns we see in the present (e.g., Gamble 2017).

\section{Documenting the Present}

Two general types of priorities emerged from our workshop regarding needs for "better documenting the present." The first is a call for a better snapshot of present-day conditions, such as ensuring that specimens and field data from the present time are represented in 
collections and long-term monitoring efforts. The second pertains to systematizing the gathering of information so that records are more likely to stay current into the future, which should help ensure that our successors will not fall behind in documentation as much as we collectively have today.

One priority for better documenting the present is to inventory existing museum and herbarium collections for key taxa and identify temporal, spatial, and taxonomic gaps that should be filled with the addition of a modern series (Funk et al. 2005). Systematic collection of even conspicuous taxa like birds has been spotty on Santa Cruz Island. For example, Greenberg and Danner (2012) measured archived specimens of a songbird from the California islands and found that bill size varied with island size; the pattern was revealed based on specimens collected an average of 91 years prior (Danner et al. 2014). Such findings can inform present-day conservation decisions, such as planning translocations (Morrison et al. 2014). Additional sampling should employ best practices, including justifying sample sizes, ensuring minimal impact on wild populations, adhering to high ethical standards when collecting specimens, and maximizing the scientific value of specimens by collecting multiple tissue types and using preservation methods that allow a variety of analyses (Suarez and Tsutsui 2004). Systematic sampling for parasites and pathogens, although often overlooked, may be especially valuable (e.g., Boyce et al. 2011, Hewson et al. 2014; Fig. 6). Finally, managers should develop priorities, based on input from the scientific community, for taxa that should be represented in frozen zoos and seed banks. For most taxa, the research value of collections from Santa Cruz Island would be greatly enhanced if sampling also occurred on other California islands or mainland sites so as to capture important variation across ranges and gradients (e.g., Fig. 4).

Another priority is to review biological research conducted on the island to identify past sampling efforts that could be repeated or resurveyed to allow a contemporary comparison (Rowe 2017). A relatively low-cost investment would be updating photo-monitoring data, or relocating positions of other photographs to establish a time series (e.g., Beltran et al. 2014). The numerous biological monitoring programs on the island (e.g., vegetation monitoring [McEachern et al. 2010], weed surveys [Knapp et al. 2009], and vegetation mapping based on aerial image interpretation [Cohen et al. 2009]) should be maintained and extended. Using the localities of existing monitoring plots to conduct other ecological studies may produce some economy of scale and enhance the richness of the overall data set. For example, Sillett et al. (2012) incorporated existing locations of study plots for long-term vegetation monitoring into the design of their survey to assess bird distribution and abundance. Interdisciplinary collaboration also may reveal opportunities to enhance existing monitoring protocols to increase their information return on investment. If, for example, abalone managers collect field measurements using the same variables as researchers studying the archeological record, they may be able to place today's observations in a much longer-term historical context (Braje et al. 2009, 2015).

Managers should create systemic means to better ensure and streamline the capture of information from ongoing research. For example, they could incorporate protocols into site access and researcher permitting processes that (1) require eventual public accessibility of data or materials, (2) define minimum standards for metadata, and (3) stipulate instructions for final disposition of biological samples (e.g., that they be archived at a natural history museum). Managers could also institute systems to opportunistically collect, voucher, and convey carcasses such as roadkills. For biological samples like blood or tissue, destructive-use protocols should consider very long-term conservation and research needs.

Another key data stream to capture is the arrivals of new species, especially given the importance of extinction and colonization rates in shaping island communities (MacArthur and Wilson 1967). Numerous marine and mainland taxa appear to be shifting their range, apparently in response to climate change (Pecl et al. 2017). Monitoring this phenomenon on the island will require an inventory of the species currently on the island and a data system for new occurrence records. Documenting how managers respond to new arrivals is similarly important: is the species considered "invasive" and thus requiring intervention (e.g., Boser et al. 2014), or is the arrival considered a "natural" range shift associated with 
climate change, and so, perhaps, "allowed"? Indeed, we expect that the documentation of management decisions will be of particular interest to future conservationists. Understanding which actions were (or were not) taken and why will help managers of the future understand why their places and resources of interest look the way they do.

Advances in network and mobile technologies create opportunities to crowdsource monitoring and information collection. For example, installing photo-monitoring signposts along trails, complete with brackets to position cameras (to standardize images) and internet uploading instructions, can engage the public in citizen science and create low-cost long-term data streams to monitor vegetation change, phenology, coastal erosion, and even visitation trends.

\section{Managing Data and Materials}

Web-based technologies offer means to improve information management and discoverability (e.g., www.californiaislands.net and www.islapedia.com). We do note, however, that if recommendations from the inquiry we advocate here are implemented, diverse types of data and materials will be generated that could compound existing challenges of archiving records over the long term. Budget constraints of research institutions may limit their capacity to receive and process data and materials. Information managers also need to be attentive to the rapid change in computer technologies to ensure that digital files remain secure and accessible into the future. As part of this inquiry, managers, researchers, and their partners need to assess options for archiving data and materials - and dedicate the resources needed to protect that legacy.

\section{Capitalizing ON Historic AND Contemporary Data and Materials}

Undertaking this inquiry and implementing recommendations from it can inform managers and scientists of the variety of resources they could tap to aid present-day decision making. For example, an inventory of museum specimens might reveal opportunities to deploy those materials to address novel questions (e.g., Fig. 6). Advances in genomics can allow for intra- and interisland comparisons to determine the distinctiveness of taxonomic forms (e.g., Fig. 4), elucidate patterns of cryptic diversity, and estimate the degree to which genotypic and phenotypic variation is adaptive, which all can be important when setting management priorities (Robertson et al. 2014, Funk et al. 2016). For example, Langin et al. (2015) discovered that bill shape of Island Scrub-Jays (Aphelocoma insularis) in pine habitats on Santa Cruz Island differed from those in oak habitats. This finding could be important if individuals need to be selected for translocation (Fig. 3) and if matching the bill form of the founder population to the habitat characteristics of the destination island is deemed important. Processing and application of remotely sensed data is also becoming ever more powerful and affordable. Timeseries imagery can reveal important patterns of vegetation change. For example, bishop pine (Pinus muricata) on Santa Cruz Island is currently experiencing widespread die-off. Analysis of patterns of past mortality events may reveal relationships with fog patterns and drought and help managers determine appropriate management responses (Fischer et al. 2009). Collaboration between researchers and managers can improve conservation efficiency by elucidating research opportunities and priorities and faciliting knowledge capture and transfer.

Building greater awareness in agencies and other public and private institutions of the current conservation value of historical archives may encourage others to initiate inquiries like the one we undertook here and help sustain the implementation of the recommendations that follow. Thus, we encourage managers and scientists to be not only deliberate about using past materials but also intentional about publicizing how those materials have benefited present-day management (e.g., Figs. 3-6). Blog posts, newsletters, and other social media are helpful tools for bringing to life the critical linkage between the future of conservation and the past.

\section{BENEFITS OF AN ARCHIPELAGO-WIDE INITIATIVE}

Organizing the effort to collect and secure data about past and present conditions as a formal initiative could have myriad collateral benefits. Implementing recommendations from the inquiry we describe would require substantial public and private investment. 
Such an interdisciplinary research enterprise may be more competitive for funding if participating scientists and partners advanced an agenda collaboratively and under an evocative banner like "Island Rediscovery Initiative." Broadly defined, a rediscovery initiative could aim to investigate, archive, and apply information about past and present conditions of a place or resource of interest, often using interdisciplinary collaboration and modern analytical approaches, to enhance understanding, appreciation, and conservation of those places and resources. A portfolio of compelling examples of the insights gained by reexamining museum collections and other historic material and data (e.g., Figs. 3-6) could help with the marketing of the initiative and in advocating funds.

Although we focused our inquiry on Santa Cruz Island, questions raised during the process highlighted the importance of considering the broader archipelago and adjacent marine and mainland areas (Fig. 2). Some priorities identified through this island-specific inquiry could form the basis of collaboration with managers and scientists working on other islands; examples might include efforts to collect a modern series of biological specimens across relevant ranges or develop a tracking system for new species arrivals. Better yet, if managers, scientists, and institutions working across the archipelago organized as a coordinated effort to identify and address the needs of the whole system, we suspect that powerful opportunities would emerge for leveraging partnerships and harnessing new resources. A variety of existing institutional networks could help galvanize this sort of initiative, such as the National Park Service's Inventory and Monitoring Network (its Mediterranean Coast Network links Channel Islands National Park to 2 other southern California mainland parks) and its Sister Parks Program (which links the park with Isla Guadalupe in Mexico; www.nps.gov/CHIS).

A coordinated and branded effort also could incorporate programs to educate and engage the public (e.g., Silvertown 2009). The California islands are just offshore of areas with millions of residents, as well as many premier research institutions. Partners in an Island Rediscovery Initiative could develop a strategic communications plan and organize field expeditions or "bioblitzes" that attract popular media, focus public attention, and build a constituency for conservation and science (Bonney et al. 2014). Pairing "rediscovery" activities on islands with similar efforts on mainland "sister sites" (e.g., "islands" of natural habitat managed by partner agencies) could provide platforms for citizen science and public education close to urban centers (Fig. 2B) that not only generate needed data but also cultivate the next generation of conservationists.

Finally, a productive and high-profile Island Rediscovery Initiative could inspire, and provide a template for, similar efforts elsewhere. Islands have long served as natural laboratories and model systems of scientific discovery (e.g., Darwin 1859, Wallace 1880, MacArthur and Wilson 1967), providing insights that help us steward the natural world (e.g., Laurance 2008). A successful Island Rediscovery Initiative would demonstrate how managers and scientists-including citizen scientists - can rise to the challenge of documenting local conditions during this moment of extraordinary global change.

\section{Concluding Remarks}

For decades, Santa Cruz Island has been the focus of extensive cross-disciplinary research. Nevertheless, our 2016 workshop identified numerous gaps in existing archives concerning the island's past and present conditions. Filling those gaps would benefit conservation decision making today and equip conservationists of the future with powerful resources. Identifying and prioritizing those gaps was greatly facilitated by interdisciplinary discussion. And in many cases, interdisciplinary collaboration will be required to address them. Our emphasis here is that the onus to address such gaps rests largely on those same managers and scientists: their responsibility stems from the fact that they are among the relatively few on the planet today who both care for the island and can access its resources. That generational imperative is the same distributed responsibility that scientists and managers share across the globe. Each must step up to ensure the sufficiency of the archives pertaining to the past and present conditions of their places and resources. Just as our generation of scientists and managers wants to have the information needed to make the most robust science-based decisions, so too will our counterparts in the 
future. And as the stewards of the moment, our accountability is to prepare them.

\section{ACKNOWLEDGMENTS}

For helpful discussion that greatly improved this paper we thank John Randall, Christina Boser, John Knapp, and the participants of the 2016 Island Rediscovery Workshops sponsored by The Nature Conservancy and the Smithsonian Institution and hosted at the Santa Barbara Museum of Natural History. We also thank the participants of a follow-up workshop convened at the Ninth California Islands Symposium in Ventura, California, who applied this "rediscovery inquiry" to the whole of the archipelago of the Californias. The collaboration among the scientists and managers working across these islands is itself an inspiring model.

\section{Literature Cited}

Barnosky, A.D., E.A., Hadly, P. Gonzalez, J. Head, P.D. Polly, A.M. Lawing, J.T. Eronen, D.D. Ackerly, K. Alex, E. Biber, AND J. BLoIs. 2017. Merging paleobiology with conservation biology to guide the future of terrestrial ecosystems. Science 355(6325):eaah4787.

Beltran, R.S., N. Kreidler, D.H. Van Vuren, S.A. MorRison, E.S. Zavaleta, K. Newton, B.R. Tershy, and D.A. Croll. 2014. Passive recovery of vegetation after herbivore eradication on Santa Cruz Island, California. Restoration Ecology 22:790-797.

Bonney, R., J.L. Shirk, T.B. Phillips, A. Wiggins, H.L. Ballard, A.J. Miller-Rushing, and J.K. Parrish. 2014. Next steps for citizen science. Science 343: 1436-1437.

Boser, C.L., C. Cory, K.R. Faulkner, J.M. Randall, J.J. KNAPP, AND S.A. MorRison. 2014. Strategies for biosecurity on a near-shore island in California. Monographs of the Western North American Naturalist 7:412-420.

Boser, C.L., T.S. Sillett, P.W. Collins, K.R. Faulkner, W.C. Funk, C.K. Ghalambor, L. Laughrin, G.B. Pauly, J.M. Robertson, R. Shea, and W. Vickers. 2018. Equipping tomorrow's historical ecologist: priorities for documenting conditions of the terrestrial fauna of Santa Cruz Island, California. Western North American Naturalist 78:879-887.

Boyce, W.M., W. Vickers, S.A. Morrison, T.S. Sillett, L. Caldwell, S.S. Wheeler, C.M. Barker, R. Cummings, AND W.K. REISEN. 2011. Surveillance for West Nile virus and vaccination of free-ranging Island Scrub-Jays (Aphelocoma insularis) on Santa Cruz Island, California. Vector-Borne and Zoonotic Diseases 11:1063-1068.

Bradley, R.D., L.C. Bradley, H.J. Garner, and R.J. BAKER. 2014. Assessing the value of natural history collections and addressing issues regarding longterm growth and care. BioScience 64:1150-1158.

Braje, T.J., J.M. ERLandson, T.C. Rick, P.K. Dayton, and M. Hatch. 2009. Fishing from past to present: long- term continuity and resilience of red abalone fisheries on California's northern Channel Islands. Ecological Applications 19:906-919.

Braje, T.J., and T.C. Rick. 2013. From forest fires to fisheries management: California anthropology, conservation biology, and historical ecology. Evolutionary Anthropology 22:303-311.

Braje, T.J., T.C. Rick, J.M. Erlandson, L. RogersBennett, and C. Catton. 2015. Historical ecology can inform restoration site selection: the case of black abalone (Haliotis cracherodii) along California’s Channel Islands. Aquatic Conservation: Marine and Freshwater Ecosystems 26:470-481.

Caballero, I., and M. Ashley. 2011. Genetic analysis of the endemic Island Loggerhead Shrike, Lanius ludovicianus anthonyi. Conservation Genetics 12: 1485-1493.

Carbone, M.S., A.P. Williams, A.R. Ambrose, C.M. Boot, E.S. Bradley, T.E. Dawson, S.M. SchaefFER, J.P. SCHIMEL, AND C.J. STILL. 2013. Cloud shading and fog drip influence the metabolism of a coastal pine ecosystem. Global Change Biology 19: 484-497.

Cayan, D.R., E.P. Maurer, M.D. Dettinger, M. Tyree, AND K. Hayhoe. 2008. Climate change scenarios for the California region. Climatic Change 87:S21-S42.

Cohen, B., C. Cory, J. Menke, And A. Hepburn. 2009. A spatial database of Santa Cruz Island vegetation. Pages 229-244 in C.C. Damiani and D.K. Garcelon, editors, Proceedings of the Seventh California Islands Symposium. Institute for Wildlife Studies, Arcata, CA.

Collins, P.W. 2009. Historic and prehistoric record for the occurrence of Island Scrub-Jays (Aphelocoma insularis) on the Northern Channel Islands, Santa Barbara County, California. Santa Barbara Museum of Natural History Technical Reports, No. 5.

CoRY, C., AND J.J. KNAPr. 2014. A program to eradicate twenty-four nonnative invasive plant species from Santa Cruz Island. Monographs of the Western North American Naturalist 7:455-464.

DAILY, M. 2012. The California Channel Islands. Arcadia Publishing, Charleston, SC.

Danner, R.M., R. Greenberg, and T.S. Sillett. 2014. The implications of increased body size in the Song Sparrows of the California Islands. Monographs of the Western North American Naturalist 7:348-356.

Darwin, C.R. 1859. On the origin of species by means of natural selection, or the preservation of favoured races in the struggle for life. John Murray, London, United Kingdom.

Erlandson, J.M., AND T.C. RICK. 2010. Archaeology meets marine ecology: the antiquity of maritime cultures and human impacts on marine fisheries and ecosystems. Annual Review of Marine Science 2:231-251.

Fischer, D.T., C.J. STill, AND A.P. Williams. 2009. Significance of summer fog and overcast for drought stress and ecological functioning of coastal California endemic plant species. Journal of Biogeography 36:783-799.

Funk, V.A., K.S. Richardson, and S. Ferrier. 2005. Survey-gap analysis in expeditionary research: where do we go from here? Biological Journal of the Linnean Society 85:549-567.

Funk W.C., R.E. LOVICH, P.A. Hohenlohe, C.A. Hofman, S.A. Morrison, T.S. Sillett, C.K. Ghalambor, J.E. 
Maldonado, T.C. Rick, and M.D. Day, ET AL. 2016. Adaptive divergence despite strong genetic drift: genomic analysis of the evolutionary mechanisms causing genetic differentiation in the island fox (Urocyon littoralis). Molecular Ecology 25:2176-2194.

Gamble, L.H. 2017. Feasting, ritual practices, social memory, and persistent places: new interpretations of shell mounds in southern California. American Antiquity 82:427-451.

GILL, K.M. 2016. 10,000 years of geophyte use among the island Chumash of the northern Channel Islands. Fremontia 44:34-38.

Gleason, M.G., J.E. Caselle, C. Caldow, R. Galipeau, W. Heady, C. Laverty, A. Little, D. Mazurkiewicz, E. O’Byrne, and D. Rosen, and S. Whitaker. 2018. Horizon scanning: survey and research priorities for coastal and marine systems of the northern Channel Islands, California. Western North American Naturalist 78:864-878.

Greenberg, R., and R.M. Danner. 2012. The influence of the California marine layer on bill size in a generalist songbird. Evolution 66:3825-3835.

Henshaw, H.W. 1886. Description of a new jay from California. Auk 3:452-453.

Hewson, I., J.B. Button, B.M. Gudenkauf, B. Miner, A.L. Newton, J.K. Gaydos, J. Wynne, C.L. Groves, G. Hendler, and M. Murray, et al. 2014. Densovirus associated with sea-star wasting disease and mass mortality. Proceedings of the National Academy of Science 111:17278-17283.

Higgs, E., D.A. Falk, A. Guerrini, M. Hall, J. Harris, R.J. Hobbs, S.T. Jackson, J.M. RhemtulLa, and W. Throop. 2014. The changing role of history in restoration ecology. Frontiers in Ecology and the Environment 12:499-506.

Hofman, C.A., T.C. Rick, M.T.R. Hawkins, W.C. Funk, K. Ralls, C.L. Boser, P.W. Collins, T.J. Coonan, J.L. King, and S.A. Morrison, ET AL. 2015. Mitochondrial genomes reveal rapid evolution of dwarf California Channel Islands foxes (Urocyon littoralis). PLOS ONE 10:e118240.

Hofman, C.A., T.C. Rick, J.E. Maldonado, P.W. Collins, J.M. Erlandson, R.C. Fleischer, C. Smith, T.S Sillett, K. Ralls, and W. Teeter, et al. 2016. Tracking the origins and diet of an endemic island canid (Urocyon littoralis) across 7300 years of human cultural and environmental change. Quaternary Science Reviews 146:147-160.

Holmes, M.W., T.T. Hammond, G.O. Wogan, R.E Walsh, K. LaBarbera, E.A. Wommack, F.M. MarTins, J.C. Crawford, K.L. Mack, and L.M. Bloch, ET AL. 2016. Natural history collections as windows on evolutionary processes. Molecular Ecology 25: 864-881.

Knapp, J.J., C. Cory, K. Walker, and R. Wolstenholme. 2009. Santa Cruz Island invasive plant species map. Pages 245-252 in C.C. Damiani and D.K. Garcelon, editors, Proceedings of the Seventh California Islands Symposium. Institute for Wildlife Studies. Arcata, CA.

Krishtalka, L., and P.S. Humphrey. 2000. Can natural history museums capture the future? BioScience 50:611-617.

Langin, K.M., T.S. Sillett, W.C. FunK, S.A. Morrison, M.A. Desrosiers, and C.K. Ghalambor. 2015. Repeated adaptive divergence within a single population. Evolution 69:653-665.
LAURANCE, W.F. 2008. Theory meets reality: how habitat fragmentation research has transcended island biogeographic theory. Biological Conservation 141: 1731-1744

Livingston, D.S. 2006. Ranches in the sea: a history of the islands within Channel Islands National Park. Department of the Interior, National Park Service, Channel Islands National Park, CA.

MacArthur, R.H., AND E.O. Wilson. 1967. The theory of island biogeography. Monographs in Population Biology. Princeton University Press, Princeton, NJ.

McClenachan, L.M. 2009. Documenting the loss of large trophy fish from the Florida Keys with historical photographs. Conservation Biology 23:636-643.

McEachern, A.K., K.A. Chess, and K.G. Niessen. 2010. Field surveys of rare plants on Santa Cruz Island, California, 2003-2006: historical records and current distributions. U.S. Geological Survey Scientific Investigations Report 2009-5264.

Menge, B.A., E.B. Cerny-Chipman, A. Johnson, J. Sullivan, S. Gravem, and F. Chan. 2016. Sea star wasting disease in the keystone predator Pisaster ochraceus in Oregon: insights into differential population impacts, recovery, predation rate, and temperature effects from long-term research. PLOS ONE 11:e0153994

Morrison, S.A. 2011. Trophic considerations in eradicating multiple pests. Pages 208-212 in C.R. Veitch, M.N. Clout, and D.R. Towns, editors, Island invasives: eradication and management. International Union for Conservation of Nature, Gland, Switzerland.

Morrison, S.A. 2014. A bird in our hand: weighing uncertainty about the past against uncertainty about the future in Channel Islands National Park. George Wright Forum 31:77-93.

Morrison, S.A., K.A. Parker, P.W. Collins, W.C. Funk, AND T.S. SILLETT. 2014. Reintroduction of historically extirpated taxa on the California Channel Islands. Monographs of the Western North American Naturalist 7:531-542.

Morrison, S.A., T.S. Sillett, W.C. Funk, C.K. GhalamBOR, AND T.C. RICK. 2017. Equipping the 22ndcentury historical ecologist. Trends in Ecology and Evolution 32:578-588.

[NPS] National Park Service. 2015. Channel Islands National Park Final General Management Plan/ Wilderness Study/Environmental Impact Statement. U.S. Department of the Interior, Washington, DC.

Nualart, N., N. Ibáñez, I. Soriano, and J. López-Pujol. 2017. Assessing the relevance of herbarium collections as tools for conservation biology. Botanical Review 83:303-325.

Ogden, A. 1975. The California sea otter trade, 1784-1848. University of California Press, Berkeley, CA.

Pecl, G.T., M.B. Araújo, J.D. Bell, J. Blanchard, T.C. Bonebrake, I. Chen, T.D. Clark, R.K. Colwell, F. Danielsen, AND B. EvengÅRD, ET AL. 2017. Biodiversity redistribution under climate change: impacts on ecosystems and human well-being. Science 355: eaai9214.

Perroy, R.L., B. Bookhagen, O.A. Chadwick, and J.T. HowarTh. 2012. Holocene and Anthropocene landscape change: arroyo formation on Santa Cruz Island, California. Annals of the Association of American Geographers 102:1229-1250.

Pesendorfer, M.B., T.S. Sillett, W.D. Koenig, and S.A. MorRison. 2016. Scatter-hoarding corvids as seed 
dispersers for oaks and pines: a review on a widely distributed mutualism and its utility to habitat restoration. Condor: Ornithological Applications 118:215-237.

Pfister, C.A., R.T. Paine, and J.T. Wootton. 2016. The iconic keystone predator has a pathogen. Frontiers in Ecology and the Environment 14:285-286.

Pinter, N., and W.D. Vestal. 2005. El Niño-driven landsliding and postgrazing vegetative recovery, Santa Cruz Island, California. Journal of Geophysical Research 110:F02003. https://doi.org/10.1029/2004 JF000203

PoLK, D.B. 1991. The island of California: a history of the myth. Arthur H. Clark Company, Spokane, WA.

Randall J.M., K. McEachern, J. Knapp, P. Power, S. JunaK, K. Gill, D. Knapp, and M. Guilliams. 2018. Informing our successors: what botanical information for Santa Cruz Island will researchers and conservation managers in the century ahead need the most? Western North American Naturalist 78:888-901.

ReEDER, L.A., T.C. Rick, AND J.M. ERLANDSON. 2012. Our disappearing past: a GIS analysis of the vulnerability of coastal archaeological resources in California's Santa Barbara Channel region. Journal of Coastal Conservation 16:187-197.

Reeder-Myers, L., J.M. Erlandson, D.R. Muhs, and T.C. Rick. 2015. Sea level, paleogeography, and archeology on California's northern Channel Islands. Quaternary Research 83:263-272.

Rick, T.C., T.J. Braje, J.M. Erlandson, K.M. Gill, L. Kirn, and L. McLaren-Dewey. 2018. Horizon scanning: survey and research priorities for cultural, historical, and paleobiological resources of Santa Cruz Island, California. Western North American Naturalist 78:852-863.

Rick, T.C., AND R. LOCKWOOD. 2013. Integrating paleobiology, archeology, and history to inform biological conservation. Conservation Biology 27:45-54.

Rick, T.C., T.S. Sillett, C.K. Ghalambor, C.A. Hofman, K. Ralls, R.S. Anderson, C.L. Boser, T.J. Braje, D.R. CAYAn, AND R.T. Chesser, ET AL. 2014. Ecological change on California's Channel Islands from the Pleistocene to the Anthropocene. BioScience 64: $680-692$

Robertson, J.M., K.M. Langin, T.S. Sillett, S.A. MorriSON, C.K. Ghalambor, and W.C. Funk. 2014. Identifying evolutionarily significant units and prioritizing populations for management on islands. Monographs of the Western North American Naturalist 7:397-411.

Robinson, J.A., D. Ortega-Del Vecchyo, Z.X. Fan, B.Y. Kim, B.M. vonHoldt, C.D. Marsden, K.E. Lohmueller, and R.K. Wayne. 2016. Genomic flatlining in the endangered island fox. Current Biology 26:1183-1189.

Roemer, G.W., C.J. Donlan, and F. Courchamp. 2002.
Golden Eagles, feral pigs, and insular carnivores: how exotic species turn native predators into prey. Proceedings of the National Academy of Sciences 99:791-796.

Rowe, R.J. 2017. Looking to the past to plan for the future. Pages 64-79 in A. Shavit and A.M. Ellison, editors, Stepping in the same river twice: replication in biological research. Yale University Press, New Haven, CT.

Schoenherr, A.A., C.R. Feldmeth, and M.J. Emerson. 1999. Natural history of the islands of California. University of California Press, Berkeley, CA.

Sholts, S.B., J.A. Bell, AND T.C. Rick. 2016. Ecce Homo: science and society need anthropological collections. Trends in Ecology and Evolution 31:580-583.

Sillett, T.S., R.B. Chandler, J.A. Royle, M. Kéry, and S.A. Morrison. 2012. Hierarchical distance sampling models to estimate population size and habitatspecific abundance of an island endemic. Ecological Applications 22:1997-2006.

Silvertown, J. 2009. A new dawn for citizen science. Trends in Ecology and Evolution 24:467-471.

Stebbins, G.L., And J. Major. 1965. Endemism and speciation in the California flora. Ecological Monographs 35:1-35.

Suarez, A.V., And N.D. Tsutsui. 2004. The value of museum collections for research and society. BioScience 54:66-74.

Sutherland, W.J., AND H.J. WoOdroof. 2009. The need for environmental horizon scanning. Trends in Ecology and Evolution 24:523-527.

Swetnam, T.W., C.D. Allen, and J.L. Betancourt. 1999. Applied historical ecology: using the past to manage for the future. Ecological Applications 9:1189-1206.

SzABÓ, P. 2015. Historical ecology: past, present and future. Biological Reviews 90:997-1014.

Vellend, M., C.D. Brown, H.M. Kharouba, J.L. McCune, AND I.H. Myers-Smith. 2013. Historical ecology: using unconventional data sources to test for effects of global environmental change. American Journal of Botany 100:1294-1305.

Wallace, A.R. 1880. Island life. MacMillan and Company, London, United Kingdom.

Willis, C.G., B. Ruhfel, R.B. Primack, A.J. MillerRushing, and C.C. Davis. 2008. Phylogenetic patterns of species loss in Thoreau's woods are driven by climate change. Proceedings of the National Academy of Sciences 105:17029-17033.

WinKer, K. 2004. Natural history museums in a postbiodiversity era. BioScience 54:455-459.

Received 12 March 2017 Revised 7 July 2017 Accepted 17 July 2017

Published online 30 October 2018 